\title{
Comparative analysis of agricultural water pricing between Azarbaijan Provinces in Iran and the state of California in the US: A hydro-economic approach
}

\author{
Marzieh Momeni ${ }^{1}$, Zahra Zakeri², Mojtaba Esfandiari², Kourosh Behzadian ${ }^{3}$, Sina Zahedi ${ }^{1 *}$, Vahid \\ Razavi $^{4}$
}

\begin{abstract}
Iranian water authority has recently announced that one of the effective ways to avoid unprecedented high water consumption in Iran's agriculture sector is to increase water price. This paper analyzes the feasibility of this policy by using a hydro-economic approach with the aim to consider the role of water pricing in agricultural water management. Such an analysis was conducted through comparing price of water consumed for producing selected agricultural crops (i.e. wheat, sugar beets, onion, tomato, barley, potato, corn, alfalfa hay and watermelon) in a case study on two provinces (East Azarbaijan and West Azarbaijan) in Iran to that in the state of California (CA) in the USA. According to the paper, the method uses the Purchasing Power Parity (PPP) Index for the first time to analyze the water prices of agricultural crops in the case study due to the specific regional circumstances in the Case Study (i.e. severe fluctuations and continuously changing currency) that prevent using the norm of Nominal Exchange Rate Index (NERI). The results show there is no significant difference between the water price for producing the selected crops in West Azarbaijan (W.AZ) and East Azarbaijan (E.AZ) provinces and that in the state of California if PPP Index is applied. Water price for producing each kilogram of some crops such as wheat, sugar beet, onion and watermelon (except potato and barley) is estimated to be between 60 to 80 percent of that in the state of California. However, this ratio is ironically equal to $116 \%$ for alfalfa hay and $105 \%$ for corn. As a result,
\end{abstract}

\footnotetext{
${ }^{1}$ Groundwater Research Institute, University of Tehran, Tehran, Iran.

${ }^{2}$ Faculty of Economics, Allameh Tabataba'i University, Tehran, Iran.

${ }^{3}$ School of Computing and Engineering, University of West London, London W5 5RF, U.K.

* Corresponding author. E-mail: zahedi.sina@ut.ac.ir.

${ }^{4}$ Research Institute for Science, Technology and Industry Policy, Sharif University of Technology, Tehran, Iran.
} 
27 considering the obtained results, one may realize that the whole problem can be hardly attributed to the low

28 price of agricultural water in our case study and raising agricultural water price would never be effective

29 for reducing water consumption in the studied area unless price adjustment accompanies developing

30 necessary infrastructures. Unlike the views that advocate raising water prices, there are two distinct views:

31 The first declares that agricultural water should be free of charge to the farmers because it returns to the

32 hydrological cycle. The second view stipulates that instead of raising water prices in agriculture sector, the

33 cost of water supply for agriculture should be reduced by new technologies. It is advised that before

34 adjusting agricultural water price, institutional reforms are required based on the experiences of other

35 countries and establishing local water distribution cooperatives.

36

37 Key words: Water pricing; Water policy reform; Sustainability; Purchasing Power Parity Index 


\section{Introduction}

An excessive exploitation of Iran's aquifers besides unscrupulous management of groundwater resources

41 through the recent decades have led to a severe water crisis in Iran (Zahedi, 2017; Yousefi et al. 2019).

42 Inefficient agriculture arising from traditional trench irrigation has caused this sector consumes over $90 \%$

43 of total water demand in Iran while Iranians are currently using more than $70 \%$ of their renewable

44 freshwater resources (Madani, 2014). On the one hand, Irresponsible management along with officials'

45 passive motions withholds Iran of having efficient regional cooperative agricultural management

46 institutions (Madani et al. 2016). However, an efficient machinery utilization, advanced irrigation

47 strategies, water quality monitoring and a Suspended Sediment Load (SSL) estimation might lead to

48 decrement of environmental impacts as well as a de-escalated water/energy consumption (Nabavi-

49 Pelesaraei et al. 2019, Kaab et al. 2019, Shamshirband et al. 2019, Chen and Chau 2016). Regarding this

50 fact that agriculture and environment are closely intertwined, increase in environmental awareness has

51 increased significantly in Iran through the recent years to mitigate the adverse environmental impacts due

52 to fast depletion of groundwater resources (Tahbaz, 2016). Indeed, due to low water price and subsidies in

53 the agriculture sector, there is no incentive for farmers to constructively contribute towards water resources

54 conservations. The current inefficient method of agriculture has intensified groundwater depletion and caused abrupt drops in groundwater tables (Nikouei and Ward, 2013).

56 Water pricing policies followed by a relevant decision making depends on a number of factors and varies

57 in different countries. Improvements in agricultural productivity, in any country or region, promote officials

58 to have large-scale investments on hydro-agricultural infrastructures (Brelle and Dressayre, 2014).

59 Actually, water can be considered as a public, a private, a common-pool and a club good. These

60 characteristics conclude that water cannot be a traditional marketable good and poor designing of markets

61 can lead to poor allocations. On the other hand, if the unique characteristics of water uses are taken into

62 account, certain aspects of water resources are matched by market processes (White, 2015). Statements 
made by some of the authorities support the idea of providing bigger subsidies for agriculture, while the opposite decision makers focus on implementing full-cost charges for irrigation water at the farm level (Massarutto, 2015). In most of the developing countries, charges to users for irrigation generally fall well short of full cost and few countries are trying to set up rules conducting farmers to pay full operation and maintenance costs (Toan, 2016). A number of countries such as Iran still continue to subsidize water by government (Mombeini et al. 2015). One of the efficient policies to decrease water consumption is to consider an elevated water price as experienced in different countries. Evidently, effective management of agricultural water in water-scarce areas requires efficient approaches (Zhang et al. 2018). Undoubtedly, Water pricing can be a key for increasing productivity of irrigated agriculture (Wang et al. 2010). Indeed, motions to the real value of water can have twofold results. Firstly, farmers will be more aware of the economic importance of water and its scarcity. Secondly, it provides incentives to farmers for shifting towards a more productive cropping pattern ( $\mathrm{Li}$ et al. 2019). Most of research works related to water pricing have dealt with raising water prices to real values and rejected full subsidies for irrigation (Tahamipour et al. 2014; Hek et al. 2018). However, institutional theory also gives a plan to researchers who investigate on the water pricing strategies based on institutional reform.

Although Shen et al. (2015) express that water is not regarded as an economic good, water pricing is a complex problem that intertwine with economic, policy, environmental and social factors. Economically, water price needs to provide all the expenses of supply related to withdrawal, transmission and distribution. Failure to do this can cause some problems in management, policy and social acceptance. For example, the water supply tariff in China before 1980s was lower than water supply cost, resulting in operation and maintenance problems and after that time when they tried to change the water tariffs they had a serious problem to regulate the new tariffs to the farmers' income because the additional costs and charges in the water tariff increased the farmers' burden. Finally, by specific arrangements, China decided to decrease the final costs of water supply instead of increase in charges. de Andrade Resende Filho et al. (2015) state that despite the fact that charges for water use in Brazil are low, representatives of the agricultural sector argue 
that they should not be charged because between $28 \%{ }^{1}$ of water withdrawals for agriculture return to the hydrological cycle. Barraque and Montginoul (2015) explain that people with low income shall be considered by policymakers while tariff for water prices is determined. This group of people should be cared by the government so that one can find "water associative houses," in which deprived people can get support for other needs and recover minimal dignity. Hernandez-Sancho et al. (2015) state two-part tariffs could be the solution in drought periods to attain an efficient water consumption. Fixed charges shall be known as the first part. Particularly, costs related to water reuse and fresh water supply can be classified into this part. Therefore, a structure for determination of fixed charges should be initially designed to ensure that all fixed costs are covered. Volumetric charges are the second part in tariffs that shall be added up to the fixed costs and met by consumers. Hence, the costs related to operation and maintenance activities, pumping infrastructures, and monitoring water quality (i.e. all volume-related costs) are categorized into this section. Montginoul et al. (2015) emphasizes that various components are engaged in calculation of irrigation costs. If most water users fail to pay the full price for any reason, other users with lower water consumption would have to incur charges, implying a degree of inefficiency and welfare losses for society at a large scale. It should be noted that presence of environmental and resources costs of water and failure to account for those costs can have impact on environmental sustainability (Bithas, 2011). In opposition, subsidies can be often harmful to the environment in terms of increasing wastes and emissions (OECD ${ }^{2}$, 2005). These wasted materials are known as pollutants and they might cause an absolute reversed effect on water quality and health indicators of the downstream lands (Alizadeh et al. 2018). However, increasing irrigation prices is expected to reduce the use of pesticides and fertilizers by changing cropping patterns and irrigation methods as well as employing new technologies ending in reduction of the amount of irrigation (Bartolini et al. 2010 and Khanali et al. 2017). Consequently, the relationship between irrigation

\footnotetext{
${ }^{1}$ There are two definitions for this issue: One- only water withdrawals to groundwater has been considered as the returned water $(\simeq 28 \%)$; two- The total amount of water coming back to hydrological cycle has been considered as returned water $(\simeq 90 \%)$.

${ }^{2}$ Organisation for Economic Co-operation and Development
} 
prices, subsidies and environmental issues should be considered by decision makers even though the

111 estimation of costs. Raising water prices based on considering environmental damage for water services

112 leads to significant political challenges (OECD, 2012). In developing countries, institutional reforms in

113 water pricing have been found more efficient rather than removing subsidies and introducing cost recovery.

114 Meanwhile, in developed countries, such as South Korea and Australia, eco-environmental institutions

115 retreat to subsidies in some cases effecting cost recoveries, even if most farmers accept to pay the full cost

116 (Toan, 2016). Tardieu (2005) expresses that irrigation is often portrayed as a public good in developing

117 countries, since it provides an incentive for the rural poor to stay in rural areas, thereby confining challenges

118 arising from relocation to crowded urban spaces. Nearly absence of knowledge over public and private

119 benefits from the perspective of water users in irrigation has escalated lack of transparency in the developing

120 countries (Tang et al. 2013). Agrawal et al. (2000) confirm that full cost recovery for irrigation water

121 includes three main components: supply cost, resource cost, and environmental cost (Figure, 1). Table 1

122 illustrates the level of subsidy to the irrigation sector over the last two decades.

Figure 1.General principles for cost of water (Agarwal et al. 2000)

Table 1. Cost components of charges in irrigation water sector of selected countries (Toan 2016)

126 In addition, Henderson \& Quandt (1985) have formerly presented a concept known as the law of demand

127 in micro-economy. They argue that when other parameters in a micro-economic law are assumed to be

128 fixed, price and demand follow an inversely proportional pattern. In Iran, following the law of demand in

129 micro-economy, irrigation pricing adjustment and modernization of irrigation systems have been remarked

130 in the sixth program of economic, social and cultural development plan as the most recently imparted

131 national mid-term program for development. This shall be attributed to an intensified water consumption 132 in agricultural sector and low price of irrigation water (World Food Program, 2017). 
Figure 2 indicates the dominant strategy of Iranian decision makers based on the law of demand by assuming constant conditions.

Figure 2: Dominant strategy of controlling water crises by Iranian decision makers (Tahamipour et al. 2014)

Since hydro-economy has engaged in the topics related to water market and pricing, one would have to initially reply to this question that water belongs to which kind of goods. In particular, while water resources can be allocated for use in economic sectors, some issues such as careful design and strong legislation shall

142 be inevitably considered to secure efficient and equitable outcomes. Again response to this question, whether water should be considered a private, a public, a club or a common good depends on the type of resources and the exploitation manners (White, 2015). Investigations on water pricing policy mainly focus on the subsidy payments and the parameters that should be considered in the calculation of water price. On the other hand, several recently published research works have concentrated on the positive impacts of

147 water price increase on the environment.

In fact, the current paper aims to discuss the accuracy of this hypothesis saying that increase in water prices would be effective to reduce water consumption, considering concerns of policy-makers about the low price of available water to farmers in Iran. The policy of raising water prices to reduce water consumption has been also mentioned in Iran's sixth program of economic, social and cultural development plan as one of the most important ways to reduce water consumption. It should be noted that policy-makers in Iran would tend to increase water price by emphasizing the difference between water prices in Iran compared to the

154 average price in the world based on NERI. Indeed, NERI is a common method to compare prices 155 internationally (to exchange prices in to United States Dollar (USD (\$))). However, the main weakness of 156 this approach is that local currency fluctuations can affect the estimated values of goods without affecting the production method. As an example, in Iran, NERI (local currency per USD (\$)) has increased from 

goods in Iran, including water has been decreased about $65 \%$ in terms of USD (\$) without considering 160 effective factors on production (technology, etc.). To avoid this problem, Economists apply PPP index 161 instead of NERI to calculate various economic indicators in different countries such as Gross Domestic 162 Product (GDP), investment rate and prices level in terms of one currency (i.e. USD (\$)). In fact, PPP index 163 indicates the real power of each currency to buy a specific unit of a product or basket of goods. In other 164 words, this index illustrates the purchasing power of two different currencies depending on differences in 165 the rate of inflation and the cost of living. For example, if the price of a Big Mac is 4.00 USD (\$) in the 166 U.S. and 2.5 Pounds sterling in Britain, we would expect the exchange rate to be $1.60(4 / 2.5=1.60)$. If the 167 exchange rate of dollars to pounds is any greater, the price of Big Mac would be overvalued in Pounds, and 168 if it is any lower, then the Big Mac price would be undervalued.

169 Following the above explanation, it should be also notified that development of effective ideas with the 170 competence of turning into an effective policy, studying all aspects of a decision and finally implementation 171 of the policy are real challenges for developing countries. Iran, as a developing country, has always been 172 involved in agricultural policy problems, specifically agricultural water pricing. That may be the underlying 173 reason why the Iranian government emphasizes on finding rational methods of water saving and preventing 174 overexploitation of resources using strict water pricing policies. On the other hand, governmental officials 175 in Iran have consistently compared the water price in Iran with that in other countries based on Nominal 176 Exchange Rate Index (NERI) without considering averaged income of farmers. Accordingly, they argue 177 that agricultural water price in Iran is much lower than the average value in the world and hence, have 178 intended to control agricultural water consumption with rising water prices in the "Sixth program of 179 economic, social and cultural development plan". Therefore, among the main purposes of the current 180 research work is to explore whether the allegations about impaired water pricing system in Iran are valid or

\footnotetext{
${ }^{1}$ Unit of Iran's Currency: Iranian Rials.
} 
not. In the line with this purpose, our group considered California State as a reference region in a developed

182 country (USA) to compare agricultural water pricing policies in both countries. Referring to the open

183 literature (Wichelns 2010), agricultural water pricing in the State of California is regulated based on

184 cropping pattern types. It means that different crops have been indexed with their water consumption as

185 well as their vitality for the region and are produced with dissimilar price of water. On the contrary, in West

186 and East Azarbaijan provinces, agricultural water subsidies have been allocated to almost all crops

187 (Statistical Yearbook of West Azarbaijan and East Azarbaijan provinces 2015), causing many policy

188 makers in Iran believe that agricultural water subsidies are the main reasons behind low water efficiency in

189 the case study.

As a result, the current research work tries to have a fundamental view by answering the following

191 questions; firstly, is the water price in Iran lower than its real value? Secondly, if the answer to the first

192 question is positive, how much increase in the price of agricultural water would be effective to control the 193 water crisis?

194 In summary, This study focuses on the above questions by analyzing the water price of the selected crops 195 in the Case Study of West Azarbaijan and East Azarbaijan provinces in Iran compared to water price of the 196 same crops in the state of California to specify agricultural water price using PPP index.

\section{Materials and Methods}

The main purpose of the present study is to find a proper reply to this question; whether water price has

201 been disregarded in producing major agricultural crops or not? In order to have a precise analysis on the 202 above issue, one requires to take note of the following process to calculate price of water consumed for 203 producing agricultural crops. 
The initial step is to calculate the price of one cubic meter water used for producing major agricultural crops in the Case Study (W.AZ and E.AZ provinces), and as the second step the above value should be

206 compared to the one cubic meter water used for the same crop in the comparing region.

207 Regarding inaccessibility of required information for evaluating the price of water used to produce per 208 unit weight of agricultural crops in Iran, Virtual Water Content (VWC) should be utilized in order to 209 calculate this factor. To complete the second step, it is also necessary to explain that water price in the state of California in the US.

211 Water scarcity in the state of California has caused many rivers, streams and aquifers to dry up. The landowners in these formerly naturally irrigated areas are currently forced to pay exorbitant prices to get water. The regional authorities of California takes water away from these districts to satisfy regional water demands regardless if it is fair at a local level in the views of these landowners (MacDonald, 2014). In other words, both districts have encountered similar problems in various areas such as drought, wide divergence between the actual cost of water and the water price which is currently paid and finally unclear policies in

217 agricultural sector having ended in major problems in both regions (MacDonald, 2014).

\subsection{Step 1: Water price calculation in Iran}

219 The price of water consumed for producing one kilogram of each crop in IRR $\left(\mathrm{C}_{\mathrm{wi}(\mathrm{Kg})}\right)$ would be calculated using the statistical information related to the water cost per one hectare of agricultural crops in IRR (

$$
\mathrm{C}_{\mathrm{wi}(\mathrm{Kg})}=\frac{\mathrm{CW}_{\mathrm{i}(\mathrm{H})}}{\mathrm{X}_{\mathrm{i}(\mathrm{H})}} ! \frac{I R R}{K g / \text { Hectar }}=\frac{I R R}{K g}
$$

224 If the cost of water to produce a kilogram of crop $i$ in Kilogram $\left(\mathrm{C}_{\mathrm{wi}(\mathrm{Kg})}\right)$ is equal to the multiplication of 225 the amount of water consumed for producing a kilogram of crop $i$ in cubic meter $\left(Q_{\text {wi }}\right)$ to the price of one 
226 cubic meter of water $\left(P_{w i}\right)$, then, the following formula (Eq. 2) would be used to calculate the price of each

227 cubic meter of water consumed for production of one kilogram crop $i$.

$$
P_{\mathrm{wi}}=\frac{\mathrm{C}_{\mathrm{wi}(\mathrm{kg})}}{\mathrm{Q}_{\mathrm{wi}}}
$$

228

229

230

231

232

233

234

235

236

237

238

239

240

241

242

243

244

245

Referring to inaccurate evaluations about the volume of water consumed for producing one kilogram of each crop, Virtual Water Content $\left(V W C_{i}\right)$ can be appreciated as a reliable parameter to express the amount of consumed water for producing a kilogram of a crop. It would be possible, therefore, to calculate water price per each kilogram of each mentioned crop considering the information available in Momeni et al. (2019) as:

$$
\text { If: } Q_{w i}=V W C_{i} \rightarrow P_{\mathrm{wi}}=\frac{\mathrm{C}_{\mathrm{wi}(\mathrm{kg})}}{\mathrm{VWC}_{\mathrm{i}}}
$$

As a result, one calculates price of water used for producing a kilogram of a crop in IRR per cubic meter. It seems that the above-mentioned method offers more advantages rather than the model only relying on water requirement of each crop and can be cited as a reliable approach to estimate the real price of water. In fact, Momeni et al. (2019) have remarked that the amount of water consumed for producing agricultural crops is more than the evaluated water requirement of each crop and it is more likely that an overestimation has stuck on calculated water price based on crops' water requirements.

\subsection{Step 2: Calculation of Water Price Comparative Index}

Now that the water price has been calculated for selected major crops, it is necessary to set criteria to analyze the valuation method. It should be notified that an agricultural water price in California has been considered as a basic criterion for water valuation in Iran, regarding the relevant similarities of the present Case Study (W.AZ and E.AZ provinces) to the state of California. 
246 In order to present a reliable comparison of the above regions, it is inevitably required to convert the water

247 price of same agricultural crops in USA and Iran to a common unit. For this purpose, Nominal Exchange

248 Rate Index (Local Currency Unit (LCU) per USD (\$), period average) is usually applied. Based on the

249 present statistical data from World Bank in 2014, Exchange Rate was equal to 25,941 IRR; In other words,

250 One USD (\$) was equal to $25,941 \mathrm{IRR}^{1}$. Hence, water price for crop i can be calculated using the following 251 equation (Eq. 4):

252

$$
\dot{P}_{W i(U S D)}=\frac{P_{w i(I R R)}}{E x R}
$$

Dividing USD (\$) price of water consumed for production of crop i in the Case Study, by the water price 255 of similar crops in the state of California gives $\propto_{i}$ that can be obtained through Eq. 5.

$$
\propto_{i}=\frac{\left(\dot{\mathrm{P}}_{\mathrm{wi}(\mathrm{USD})}\right)_{\mathrm{WEAZP} \text { West Azarbaijan and East Azarbaijan provinces }}}{\left(\mathrm{P}_{\mathrm{wi}(\mathrm{USD})}\right)_{\mathrm{CA}}}
$$

If $\propto_{i}>1$, the Case Study's water price for producing crop i is more than that in California for a similar crop; or if $\propto_{i}<1$, this value is naturally lower in our case of study region.

Indeed, the NERI plays a key role in this analysis, and it should be taken into account that the Exchange

260 Rate in Iran is almost set based on imperative policies dictated by governments. Therefore, the above 261 method is likely to generate inaccurate results considering effects of fluctuations. By the aim to avoid imprecisions, PPP Index is applied to minimize the estimated errors and unify the price of water in the Case Study and the state of California. Purchasing Power Parity (PPP) is an economic index which is used to determine the value of national currency in different countries through a basket of goods. PPP is a price relative, showing the ratio of the prices in national currencies of the same good or service in different

\footnotetext{
${ }^{1}$ In early 2018, Iranian Rials has devalued and Each USD (\$) is exchanged to 143600 IRR in the free market.
} 
countries (Schreyer and Koechlin, 2002). PPP conversion factor is the number of units of a country's

267 currency required to buy the same amounts of goods and services in the domestic market as USD (\$) would

268 buy in the United States (World Bank, 2015). In other words, the equality of purchasing power between the

269 (A) and (B) countries is the number of national currency units of country (A), whose value is as much as

270 the purchasing power of a national currency of country (B). Accordingly, PPP can be calculated from the

271 following equation:

$$
P P P_{B . A}=\frac{P_{A}^{i}}{P_{B}^{i}}
$$

272

273 where $P_{A}^{i}$ is the price of goods or basket of goods (i) for national currency of country (A) and $P_{B}^{i}$ is the 274 price of goods or basket of goods (i) for national currency of country (B). PPP can provide international 275 comparisons as an exchange rate or a conversion factor in terms of a common currency by converting the 276 value of different economic indicators (Schreyer and Koechlin, 2002).

277 So the equation 7 can be reformed as follows:

$$
\stackrel{P}{P}_{W i(U S D)}=\frac{P_{w i(I R R)}}{P P P}
$$

279 According to the present statistical data from World Bank (2015), one USD (\$) was found to be equal to 2807364 IRR when the exact value of exchange rate was calculated based on PPP. Imagine, a service costs 1 281 USD (\$) in the United States. This service should cost 7364 IRR based on the PPP index in Iran, while 282 the actual price of the service is around 0.284 USD (\$) in Iran. In fact, when it comes to analysis based on 283 the PPP index, price of a basket of goods and services is no more equal to the exchange rate.

284 Finally, equation 8 can be obtained from conflation of equations 5 and 7 as follows:

$$
\dot{\alpha}_{i}=\frac{\left(\dot{\mathrm{P}}_{\mathrm{wi}(\mathrm{USD})}\right)_{\mathrm{WEAZP}}}{\left(\mathrm{P}_{\mathrm{wi}(\mathrm{USD})}\right)_{\mathrm{CA}}}
$$


285 286

287

288

289

290

291

292

293

294

295

296

297

298

299

300

301

302

303

304

305

306

307

308

309

04

As formerly mentioned, $\alpha_{i}$ presents all features related to $\propto_{i}$.

\section{Case Study}

\subsection{East Azarbaijan and West Azarbaijan Provinces}

East Azarbaijan (E.AZ) and West Azarbaijan (W.AZ) provinces are located in the north-west of Iran and surrounded by Kordestan and Zanjan provinces from the south, Turkey and Iraq from the west and Armenia, Republic of Azerbaijan, and Nakhchivan autonomous republic from the north side of the limited area (Figure 3). The area of the Case Study is about $82,550 \mathrm{~km}^{2}$ with an elevation between 140 and 4,151 meters above mean sea level (AMSL). The mean annual temperature of the Case Study is about $16 \mathrm{C}^{\circ}$. The average annual precipitation amount in this region $(358 \mathrm{~mm})$ is higher than the average value in Iran $(250 \mathrm{~mm})$. Moreover, neighboring regions have close identical climatic characteristics with the Case Study such as Van province (in Turkey with $386 \mathrm{~mm}$ ), Nakhchivan autonomous republic (280 mm) and Ardabil province (335 mm). The study area shares parts of four drainage basins including Aras, Urmia Lake, Sefid rood and West border. The areas of these shared drainage basins are given in Table 2.

Figure 3: Location of the Studied-Area

Based on Table 2 and Figure 4, Lake Urmia Basin covered most of the current studied area. According to the sustainable development index of The United Nations Educational, Scientific and Cultural Organization (UNESCO) for water resources, this basin is belonged to the high risk category $(40 \%<)$. Figure 4 shows 
the location of all basins in the studied area. The total amount of water consumption in the studied area is

311 approximately 10.91 Billion Cubic Meters (BCM). The estimations indicate the total amount of water 312 consumption in agriculture sector is approximately 10.02 BCM (91.8\%), while 712 Million Cubic Meters 313 (MCM) $(6.5 \%)$ is consumed for health and domestic sectors and $184 \mathrm{MCM}(1.7 \%)$ is consumed for 314 industrial uses. Out of the total water used in agriculture, 9.52 BCM is used for a number of selected crops 315 including wheat, sugar beets, onion, tomato, barley, potato, corn, alfalfa hay and watermelon, which are 316 analyzed in this study.

Figure 4: Location of all basins in the Case Study

\subsection{California as a comparing region}

321

322

323

324

325

326

327

328

329

330

331

332

333

334

The state of California is located in the Pacific Region of the United States of America. This area has settled in the south west of USA stretching from the Mexican border along the Pacific Ocean and occupying third place in terms of states' land areas with $423,970 \mathrm{~km}^{2}$. Its terrain includes cliff-lined beaches, redwood forest, the Sierra Nevada Mountains, Central Valley farmland and the Mojave Desert. California's climate varies widely, from arid to humid, depending on latitude, elevation, and proximity to the coast. The State is surrounded by the state of Oregon from the north, the state of Nevada from the East and Mexico From the south while having a direct access to the Pacific Ocean from the West. The State expands from $114^{\circ} 08^{\prime}$ (W) to $124^{\circ} 24^{\prime}(\mathrm{W})$ and $32^{\circ} 30^{\prime}(\mathrm{N})$ to $42^{\circ} 00^{\prime}(\mathrm{N})$ with the elevation of -85 to 4421 meters above mean sea level (AMSL). The mean annual temperature of the State is about $16 \mathrm{C}^{\circ}$ and the average annual precipitation amount is approximately $544 \mathrm{~mm}$ (Figure 5). The reason for selecting the state of California for comparing to W.AZ and E.AZ provinces was the identical risks threatening both regions in terms of the water crisis.

According to the current drought years in California, a big fraction of the essential storage source and reserves of California's water system was consumed to deliver enough water to the state. As water in 
California becomes less abundant, or less available due to competing demands, the water use by irrigated crops would need to be balanced against the economic and nutritive benefits of those crops (Fulton et al. 2018). A 2011 study indicated that the Central Valley Aquifer is losing an amount of water each year equivalent to nearly 29 million acre-feet of water found in Lake Mead, the nation's largest surface reservoir on the Colorado River (Dimick 2015).

To make a clear view for both regions, table 3 illustrates the areas of planting crops as well as crop yield of each region for all selected crops in W.AZ and E.AZ provinces and the state of California.

Table 3: Areas of planting crops and the crop yield of selected crops in W.AZ and E.AZ provinces and the state of California Figure 5: Location of comparing region (the state of California)

\section{Results}

Referring to the explanations of the previous section, price of water consumed for production of each agricultural crop -within the Case Study region- should be estimated. Table 4 demonstrates estimations related to the price of one cubic meter water used in production of selected crops in W.AZ and E.AZ 352 provinces: 
As the next action, it is required to convert the currency of Iran (IRR) to USD (\$) for comparing the price of one cubic meter water in both regions. The Exchange Rate proportion in the year 2014 (IRR vs. USD (\$)) has been utilized for this purpose. Table 5 indicates this issue, as follows:

Table 5: Comparing the price of one cubic meter water used in producing selected agricultural crops in W.AZ and E.AZ provinces to that in the state of California by converting IRR to USD (\$)

As it is perceived, $\alpha$ index has been calculated to be lower than 1 for all of the selected crops. Moreover, one can find out that the price of water used for producing the selected crops in the Case Study is lower than that in the state of California, whereas the results would be different using Purchasing Power Parity (PPP) Index.

Table 6: Estimation of the price of one cubic meter water used for producing selected crops using Purchasing Power Parity (PPP) based on USD (\$)

According to the results presented by Table $6, \stackrel{\alpha}{\alpha}$ index is lower than 1 , nearly for all of the selected crops except alfalfa hay and Corn. In other words, the price of water used for producing most of the selected crops

375 in the Case Study is lower than that in the similar regional condition, the state of California.

376 It needs to be mentioned that price of water consumed for producing some crops such as Wheat, Sugar beet,

377 Onion and Watermelon, in the Case Study, is estimated to be between 60 to 80 percent of water price in the 378 state of California while a significant difference was only observed on potato and barley.

379 Therefore, in response to this question; whether water price for producing specific agricultural products in 380 W.AZ and E.AZ provinces are lower than that of analogous crops in California or not, one might notice 381 that water price for nearly $22 \%$ of the studied crops in the Case Study was found to be higher. In $44 \%$ of the crops, water price in the Case Study was estimated to be between 60 to 80 percent of the cost in the 
comparing region. Contrary to the public perception, the water price for producing only $33 \%$ of the studied crops in the Case Study was found to be lower than a similar case of study. As a result of the above explanation, it is a doubtful statement saying that low price of water in W.AZ and E.AZ provinces (even Iran) is the sole underlying reason behind the current water crisis.

387 In line with the above analysis, it should also be recognized whether price adjustment contributed to 388 avoiding dire consequences of the impending water crisis or could at least ease the effects. As a response 389 to this question, one might declare that based on techniques of Institutionalism, adjustment or water price manipulation could be the final legislative phase and before that, necessary institutional reforms are required (Stiglitz, 2002). Indeed, success or failure of the price adjustment policy of water input in Iran depends on the success of the state in preparing the above-mentioned platforms.

It needs to be noted that, some countries are trying to increase their irrigation efficiency by planning on supportive policies and pricing the real value of water in their agriculture sector. As it is obvious, agriculture sector in many countries is the most important demander of water input and clearly, supportive policies can axiomatically be considered as the first step to face water crisis. In other words, it is expected that a specific framework should be provided to control the water resources crisis through price adjustment strategies and empowering the agriculture sector through setting supportive policies. Table 7 indicates important supportive policies for agriculture sector in some countries.

400

Table 7: Supportive policies for agriculture sector as the main demander of water in some countries (Allen

Agriculture sector demands the biggest share of water resources by consuming over 90 percent of annual 405 volume of water extraction (Banouei et al. 2015). Therefore, it seems that setting supportive policies in this 406 sector has a high importance in the course of confronting and controlling water crisis. In this context, some 407 of the supportive policies such as varied insurances for farmers, tax exemptions and guaranteed prices could 
be mentioned. Probably, due to specific reasons such as the differences in the details of these policies and applied performance procedure, the level of achieving desired goals in Iran was different to other countries.

\section{5. Conclusions}

Results of the study represented that level of the water price for each kilogram of the mentioned agricultural crops in W.AZ and E.AZ provinces is not significantly different from the same crops in the state of California. Therefore, it seems that a hypothesis saying that "water price in Iran is far less than the rest of the world" has stemmed from a comparison between water prices in Iran with the international level of costs based on the NERI. Indeed, if PPP index was involved in the policy analysis -as a valid index to compare the level of water prices in different countries- instead of NERI, the results of the studies would

419 be different.

Based on a microeconomic analysis, although, an increase in the price of goods is expected to reduce demands for it, water is naturally a different substance on which people's lives essentially depend on. Considering several economic theories, demands for essential goods like water are categorized into the class of inelastic or relatively inelastic demands. Such kinds of demands can be barely affected by price adjustment policies as usage of these goods is of such importance to consumers, that it would not be easy to reduce their consumption or replace them by other goods after raising prices. Likewise, as a basic intermediate input, water shall be consumed in the process of manufacturing several principal products and any increases in the price of water may lead to impose elevated costs to consumers in agriculture sector. Hence, it is not easy to argue that the price adjustment could work successfully as the main strategy to reduce water demand and cope with the water crisis in Iran.

In this regard, four levels of social analysis have been elucidated by Williamson (2000) considering analytical framework of Institutionalism. Quote to his explanation; while "culture" as the first level and the most significant part develops its components, and the second level affairs such as legal bases, institutions 
and infrastructures are well-regulated and finally management, implementation and oversight in the third

434 level act more desirable, one can expect that the desired achievements categorized into the fourth level are

435 appeared. Therefore, in water pricing issue, any administrative policy-making requires to have harmony

436 with the culture of people who are the main targets of the policy. This would definitely result in achieving

437 public acceptance in the target community. Secondly, legal requirements (for guarantee) as well as

438 infrastructural requirements (for fulfillment) must be provided in the target society. Overall, before

439 considering water as a type of goods such as common good, public good, private good, and club good, it is

440 necessary to set a collection of institutional infrastructures as well as prerequisites that create public

441 acceptance of the policy adopted through the use of public education programs for the development and

442 modification of water use patterns. Following this policy, we can anticipate that the mentioned institutions

443 would enable making effective decisions for an optimum pattern of water consumption and its types of

444 good for different consumptions. That entails considering varied supportive facilities and promotions to

445 public users, more importantly in agriculture sector. The logic behind such a policy is to let policy-makers

446 control consumers' behavior and gain their companionship with subsequent price reforms.

447 In addition, the studies on the price of water consumed for producing selected agricultural crops in the state

448 of California indicated that water pricing process followed a programmatic approach in this state.

449 Alfalfa hay and corn, for instance, were excluded from this compatibility as both were undeniably 450 recognized major food requirements in the US. Regarding Environmental Working Group (EWG) (2016)

451 information, during only the year 2016, over 13 million USD (\$) have been paid to local farmers in 452 California for corn subsidies. Moreover, Fox (2015) argues that importance of Dairies, in the state, forces 453 policymakers to keep the price of irrigation at a low level in California. What should be taken into account 454 is that the ultimate price of alfalfa hay provision - as the primary source of livestock food-is critical to Diary 455 industries distressing the cost of related products. Therefore due to the importance of diary supplies in the 456 health sector and considering this fact that both alfalfa hay and corn are vastly utilized as intermediate 457 inputs in the production chain of other commodities, subsidies shall be inevitably enforced. 
Referring to the results mentioned in the paper, However, referring to Table 6, one might easily construe that there is no highlighted discrepancy between the total agricultural water price in the case study and comparing region using USD (\$) equivalent prices based on Purchasing Power Parity (PPP) index.

461 Moreover, taking advantages of PPP index instead of NERI revealed this fact that agricultural water prices 462 in California for corn and alfalfa hay are slightly lower than that in our Case Study. As a result, one might 463 suggest that increasing agricultural water prices can hardly be an ideal solution and its only effect is 464 escalating farmers' living costs instead of an efficient water price adjustment.

465 As stated by Stiglitz (2002), based on the techniques of Institutionalism, adjustment or water price 466 manipulation could be the final legislative phase and before that, necessary institutional reforms are 467 required. Therefore, Iranian interdisciplinary researchers working in the field of "Environmental Economy" 468 believe that price manipulation would render insignificant effects on agricultural water consumption as long 469 as Iranian officials evade institutional reforms in agriculture sector. In particular, there are a number of essential measures that have to be taken by the authorities; such as planning to allocate water subsidies to only strategic crops, promoting farmers to change their cultivation patterns based on the regional limitations and providing appropriate infrastructures for farming. Hence, based on findings of the present paper,

473 implementation of the "Sixth Development Plan" might to some extent ease the problems of agriculture 474 sector in our case of study but there are still essential details that have to take into account for guaranteeing 475 the success of a decision or policy.

476

477 The current paper would present following suggestions as future plans to confront the impending water 478 crisis:

479 1. It is necessary to investigate the issue of water crisis in a rational space considering all aspects such as the nature and vital features of water. This is a key to avoid any premature decision making.

2. Success of the policies relating to water consumption patterns depends on providing adequate infrastructures that enable consumers to accept optimal profiles and follow relative instructions. In 
line with the above purpose, significant measures shall be taken such as culture making and public education, providing supportive financial facilities to farmers, crop insurance premiums in catastrophic situations, facilitating farmers to gain access to modern technologies, improving water

Limited access to accurate, reliable and updated statistical sources was one of the serious problems of the present research work. Specifically, finding annual reports with an overlapped area of information for the case study and the comparing region as well as making the comparison based on correlated information and row data for both regions were genuine challenges in the process of this research. For future works, the authors would suggest studying prerequisites of an effective policy making such as necessary measures that 494 shall be taken before putting a decision into practice. Some infrastructures are also required prior to implementing price adjustment. In addition, costs and benefits of the above proceedings should be evaluated 496 as real matters of concern. 


\section{References}

1. Agarwal, A., de Los Angeles, M.S., Bhatia, R., Chéret, I., Davila-Poblete, S., Falkenmark, M., Gonzalez Villarreal, F., Jønch-Clausen, T., AïtKadi, M., Kindler, J., Rees, J., Roberts, P., Rogers, P., Solanes, M., Wright, A., 2000. Integrated water resources management, in: Technical Advisory Committee (TAC) Backgrounds Papers No.4, Global Water Partnership, Stockholm, Sweden, [Retrieved March $\left.1^{\text {st }}, \quad 2000\right]$, https://www.gwp.org/globalassets/global/toolbox/publications/background-papers/04-integrated-water-resourcesmanagement-2000-english.pdf.

2. Alizadeh M.J., Kavianpour M.R., Danesh M., Adolf J.E., Shamshirband S., Chau K.W., 2018. Effect of river flow on the quality of estuarine and coastal waters using machine learning models, Eng Appl Comp Fluid, 12 (1), 810823, https://doi.org/10.1080/19942060.2018.1528480.

3. Allen, M., 2016. Forms of farm support/subsidy as operated in selected countries and associated conditions, Research and Information Service Briefing, Northern Ireland Assembly, Paper 77/16, NIAR 224-16, [Retrieved October $\left.\quad 27^{\text {th }}, \quad 2016\right], \quad \underline{\text { http://www.niassembly.gov.uk/globalassets/documents/raise/publications/2016- }}$ 2021/2016/aera/7716.pdf.

4. Banouei, A.A., Banouei, J., Zakeri, Z., Momeni, M., 2015. Using Input-output Model to Measure National Water Footprint in Iran, Journal of business perspective, 14 (2), 75-87, ISSN: 0972-7612, [Retrieved November 2 ${ }^{\text {nd }}, 2015$ ], https://www.bimtech.ac.in/Uploads/image/354imguf_BP-2015-14-No.-2July-Dec-issue.pdf.

5. Barraque, B., Montginoul, M., 2015. How to Integrate Social Objectives into Water Pricing, in: Dinar, A., Pochat, Dordrecht, 359-371, https://doi.org/10.1007/978-3-319-16465-6_18.

6. Bartolini, F., Gallerani, V., Raggi, M., Viaggi, D., 2010. Water management and irrigated agriculture in Italy: Multicriteria analysis of alternative policy scenarios. Water Policy, 12, 135-147, https://doi.org/10.2166/wp.2009.158.

7. Bithas, K., 2011. Sustainability and externalities: Is the internalization of externalities a sufficient condition for sustainability?, Ecol. Econ., 70, 1703-1706, https://doi.org/10.1016/j.ecolecon.2011.05.014.

8. Brelle, F., Dressayre, E., 2014. Financing irrigation, Irrig. and Drain., 63, 199-211, https://doi.org/10.1002/ird.1836.

9. Chen, X.Y. and Chau, K.W., 2016. A hybrid double feedforward neural network for suspended sediment load estimation', Water Resour Manage, 30 (7), 2179-2194, https://doi.org/10.1080/10.1007/s11269-016-1281-2. 
10. de Andrade Resende Filho, M., Ortiz-Correa, J.S., de Oliveira Torres, M., 2015. Water Pricing in Brazil: Successes, Failures, and New Approaches, in: Dinar, A., Pochat, V., Albiac-Murillo, J. (Eds.) Water pricing experiences and innovations. Springer International Publishing, Dordrecht, 41-61, https://doi.org/10.1007/978-3-319-16465-6_3.

11. Dimick, D., 2015. 5 Things You Should Know About California's Water Crisis, National Geographic, [Retrieved April $\left.6^{\text {th }}, 2015\right]$, https://news.nationalgeographic.com/2015/04/150406-california-drought-snowpack-map-waterscience/.

12. Environmental Working Group (EWG), 2016. Corn Subsidies in California, https://farm.ewg.org/top_recips.php?fips=06000\&progcode=corn\&yr=2016\&regionname=California Source).

13. Fox, J., 2015. Why California Needs Thirsty Alfalfa, Bloomberg, [Retrieved May 26 ${ }^{\text {th }}$ 2016], https://www.bloomberg.com/view/articles/2015-05-26/why-they-grow-thirsty-alfalfa-in-parched-california.

14. Fulton, J., Norton, M., Shilling, F., 2018. Water-indexed benefits and impacts of California almonds, Ecol. Indic., 96, 711-717, https://doi.org/10.1016/j.ecolind.2017.12.063.

15. Hek, K.T., Ramli, M.F., Iryanto, I., Goh, S.R., Zaki, M.F.M., 2018. Generalization of Water Pricing Model in Agriculture and Domestic Groundwater for Water Sustainability and Conservation, E3S Web of Conferences, 34, 02008, https://doi.org/10.1051/e3sconf/20183402008.

16. Henderson, J.M., Quandt, R.E., 1985. Microeconomic Theory: A Mathematical Approach, Third Edition, McgrawHill Book Company, New York, USA.

17. Hernandez-Sancho, F., Molinos-Senante, M., Sala-Garrido, R., 2015. Pricing for Reclaimed Water in Valencia, Spain: Externalities and Cost Recovery, in: Dinar, A., Pochat, V., Albiac-Murillo, J. (Eds) Water pricing experiences and innovations. Springer International Publishing, Dordrecht, 431-442, https://doi.org/10.1007/978-3-319-164656 -22.

18. Iran Investment and Business Guide (IIBG), 2016. Vol. 1: Strategic and practical information, International Business Publications, Washington, USA.

19. Kaab, A., Sharifi, M., Mobli, H., Nabavi-Pelesaraei, A., Chau, K.W., 2019. Combined life cycle assessment and artificial intelligence for prediction of output energy and environmental impacts of sugarcane production, Sci Total Environ, 664, 1005-1019, https://doi.org/10.1016/j.scitotenv.2019.02.004.

20. Khanali, M., Mousavi, S.A., Sharifi, M., Keyhani-Nasab, F., Chaw, K.W., 2018. Life cycle assessment of canola edible oil production in Iran: a case study in Isfahan Province, J Clean Prod, 196, 714-725, https://doi.org/10.1016/j.jclepro.2018.05.217. 
21. Li, M., Xu, W., Zhu, T., 2019. Agricultural Water Allocation under Uncertainty: Redistribution of Water Shortage Risk, Am J Agr Econ, 101 (1), 134-153, https://doi.org/10.1093/ajae/aay058.

22. MacDonald, S., 2014. California's Water Crisis-The Black Hole of Water (Master's Thesis), University of Puget Sound, North Tacoma, Washington, USA, [Retrieved October $1^{\text {st }}$ 2015], https://www.pugetsound.edu/files/resources/mcdonaldcaliforniaswatercrisistheblackholeofwater.pdf.

23. Madani, K., 2014. Water management in Iran: what is causing the looming crisis, J. Environ. Stud. Sci., 4 (4), $315-$ 328, https://doi.org/10.1007/s13412-014-0182-z.

24. Madani, K., AghaKouchak, A., Mirchi, A., 2016. Iran's Socio-economic Drought: Challenges of a Water-Bankrupt Nation, Iranian Studies, 49 (6), 997-1016, http://dx.doi.org/10.1080/00210862.2016.1259286.

25. Massarutto, A., 2015. Water Pricing in Italy: Beyond Full-Cost Recovery, in: Dinar, A., Pochat, V., Albiac-Murillo, J. (Eds) Water pricing experiences and innovations. Springer International Publishing, Dordrecht, 201-230, https://doi.org/10.1007/978-3-319-16465-6_11.

26. Mombeini, H.A., Rezaei, S., Nadarajah, S., Emami, M., 2015. Reducing Water Consumption after Targeted Subsidy Plan in Iran, Water Resour., 42, 389-396, https://doi.org/10.1134/S0097807815030100.

27. Momeni, M., Zakeri, Z., Zahedi, S., Razvi, V., 2019. Investigation on water content of selected agricultural products of East Azarbaijan and West Azarbaijan, IJHST, 9 (2), 189-200, https://doi.org/10.1504/IJHST.2019.098163.

28. Montginoul, M., Loubier, S., Barraque, B., Agenais, A.L., 2015. Water Pricing in France: Toward More Incentives to Conserve Water, in: Dinar, A., Pochat, V., Albiac-Murillo, J. (Eds.) Water pricing experiences and innovations. Springer International Publishing, Dordrecht, 139-160, https://doi.org/10.1007/978-3-319-16465-6_8.

29. Nabavi-Pelesaraei, A., Rafiee, S., Mohtasebi, S.S., Hosseinzadeh-Bandbafha, H., Chau, K.W., 2019. Assessment of optimized pattern in milling factories of rice production based on energy, environmental and economic objectives, Energy, 169, 1259-1273, https://doi.org/10.1016/j.energy.2018.12.106.

30. Nikouei, A., Ward, A.F., 2013. Pricing irrigation water for drought adaptation in Iran, J. Hydrol., 503, 29-46, https://doi.org/10.1016/j.jhydrol.2013.08.025.

31. Organisation for Economic Co-operation and Development (OCED), 2005. Environmentally harmful subsidies: challenges for reform, OECD Publishing, Paris, France, [Retrieved August 11 ${ }^{\text {th }}$ 2005], https://doi.org/10.1787/9789264012059-en.

32. Organisation for Economic Co-operation and Development (OECD), 2012. Water quality and agriculture: meeting the policy challenge, OECD studies on water, OECD Publishing, Paris, France, [Retrieved March 12 ${ }^{\text {th }}, 2012$ ], https://doi.org/10.1787/9789264168060-en. 
33. Schreyer, P., Koechlin, F., 2002. Purchasing power parities - measurement and uses, OECD, [Retrieved March $31^{\text {st }}$, 2002], https://www.oecd.org/sdd/prices-ppp/2078177.pdf.

34. Shamshirband, S., Jafari-Nadoushan, E., Adolf, J.E., Manaf, A.A., Mosavi, A., Chau, K.W., 2019. Ensemble models with uncertainty analysis for multi-day ahead forecasting of chlorophyll a concentration in coastal waters, Eng Appl Comp Fluid, 13 (1), 91-101, https://doi.org/10.1080/19942060.2018.1553742.

35. Shen, D., Yu, X., Shi, J., 2015. Introducing New Mechanisms into Water Pricing Reforms in China, in: Dinar, A., Pochat, V., Albiac-Murillo, J. (Eds.) Water pricing experiences and innovations. Springer International Publishing, Dordrecht, 343-358, https://doi.org/10.1007/978-3-319-16465-6_17.

36. Statistical Yearbook of West Azarbaijan and East Azarbaijan provinces, 2015. Plan and Budget Organization, Statistical Center of Iran. In Persian.

37. Stiglitz, J.E., 2002. Globalization and its discontents, First Edition, W.W. Norton and Company, New York, USA.

38. Tahamipour, M., KavoosiKalashami, M., Chizari, A., 2014. Irrigation Water Pricing in Iran: The Gap between Theory and Practice, IJAMAD, 5 (2), 109-116.

39. Tahbaz, M., 2016. Environmental Challenges in Today's Iran, Iranian Studies, 49 (6) 943-961, http://dx.doi.org/10.1080/00210862.2016.1241624.

40. Tang, Z., Nan, Z., \& Liu, J., 2013. The willingness to pay for irrigation water: a Case Study in Northwest China, Global Nest J., 15 (1), 76-84, https://doi.org/10.30955/gnj.000903.

41. Tardieu, H., 2005. Irrigation and drainage services: some principles and issues towards sustainability-an ICID Position Paper, Irrig. and Drain., 54, 251-262, https://doi.org/10.1002/ird.172.

42. Toan, T.D., 2016. Water Pricing Policy and Subsidies to Irrigation: a Review, Environ. Process, 3 (4), 1081-1098, https://doi.org/10.1007/s40710-016-0187-6.

43. UC-Davis, 2015. Sample costs to establish and produce different crops, UC Davis Cost Studies database, https://coststudies.ucdavis.edu/en/current (Online Source).

44. U1 Hassan, M., Sarwar-Qureshi, A., Heydari, N., 2007. A Proposed Framework for Irrigation Management Transfer in Iran: Lessons from Asia and Iran, International Water Management Institute, 37 pp., IWMI Working Paper 118, Colombo, Sri Lanka, http://dx.doi.org/10.3910/2009.299.

45. Wang, J., Huang, J., Zhang, L., Huang, Q., Rozelle, S., 2010. Water Governance and Water Use Efficiency: The Five Principles of WUA Management and Performance in China, JAWRA, 46 (4), 665-685, https://doi.org/10.1111/j.1752-1688.2010.00439.x. 2015], http://www.globalwaterforum.org/2015/04/27/understanding-water-markets-public-vs-private-goods/. 
47. Wichelns, D., 2010. Agricultural Water Pricing: United States, Sustainable Management of Water Resources in Agriculture, OECD Publishing, Paris, [Retrieved March 2nd , 2010], https://doi.org/10.1787/9789264083578-16-en.

48. Williamson, O.E., 2000. The New Institutional Economics: Taking Stock, Looking Ahead, J. Econ. Lit., 38 (3), 595613, https://doi.org/10.1257/jel.38.3.595.

49. World Bank, 2015. Purchasing Power Parities and the real size of world economies, a comprehensive report of the 2011 international comparison program, International Bank for Reconstruction and Development, The World Bank, Washington, USA, https://doi.org/10.1596/978-1-4648-0329-1.

50. World Bank, (n.d). PPP conversion factor, GDP (LCU per international \$), International Comparison Program database, https://data.worldbank.org/indicator/PA.NUS.PPP?end=2017\&start=2002 (Online Source).

51. World Food Program (WFP), 2017. Draft Islamic Republic of Iran Interim Country Strategic Plan (2018-2020),

Presidential Administration of Islamic Republic of Iran, [Retrieved August 18 ${ }^{\text {th }}$ 2017], https://documents.wfp.org/stellent/groups/public/documents/resources/wfp292695.pdf.

52. Yousefi, H., Zahedi, S., Niksohkahn, M.H., Momeni, M., 2019. Ten-year prediction of groundwater level in Karaj plain (Iran) using MODFLOW2005-NWT in MATLAB, Environ. Earth Sci., In Press, https://doi.org/10.1007/s12665-019-8340-y.

53. Zahedi, S., 2017. Modification of expected conflicts between Drinking Water Quality Index and Irrigation Water Quality Index in water quality ranking of shared extraction wells using Multi Criteria Decision Making techniques, Ecol. Indic., 83, 368-379, https://doi.org/10.1016/j.ecolind.2017.08.017.

54. Zhang, S., Wang, X., Li, H., 2018. Modeling and computation of water management by real options, J. Ind. Manag. 


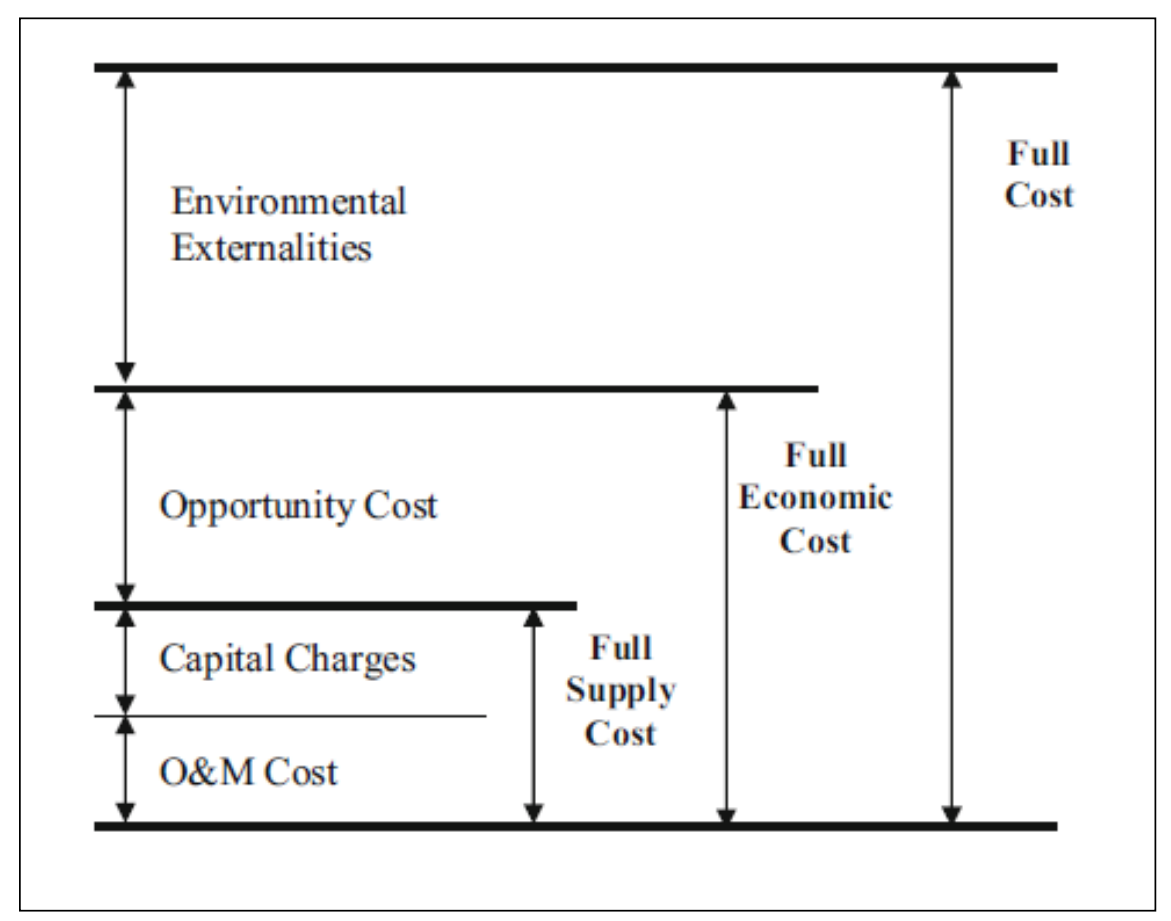

Figure 1.General principles for cost of water (Agarwal et al. 2000)

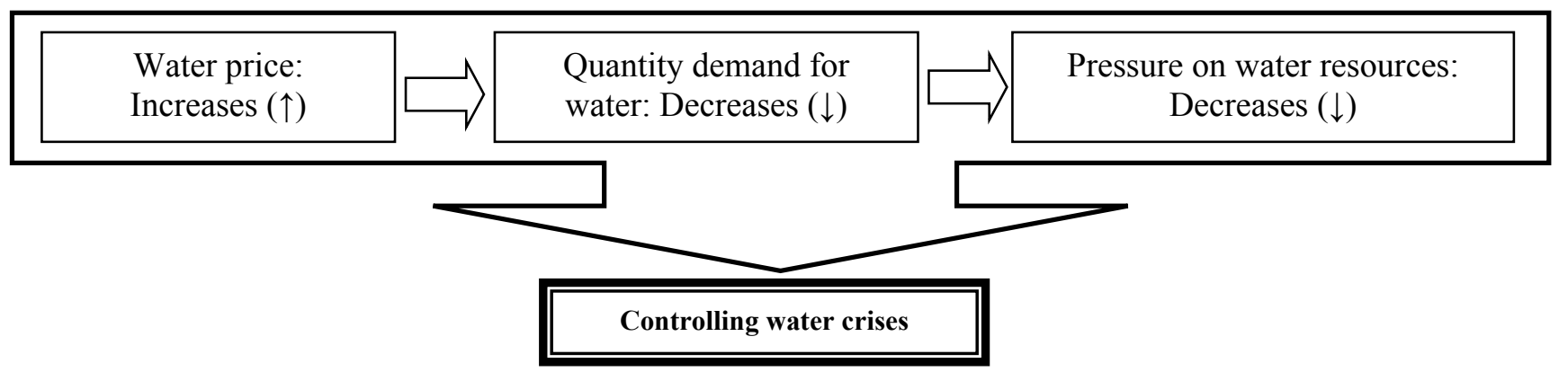

Figure 2: Dominant strategy of controlling water crises by Iranian decision makers (Tahamipour et al. 2014) 


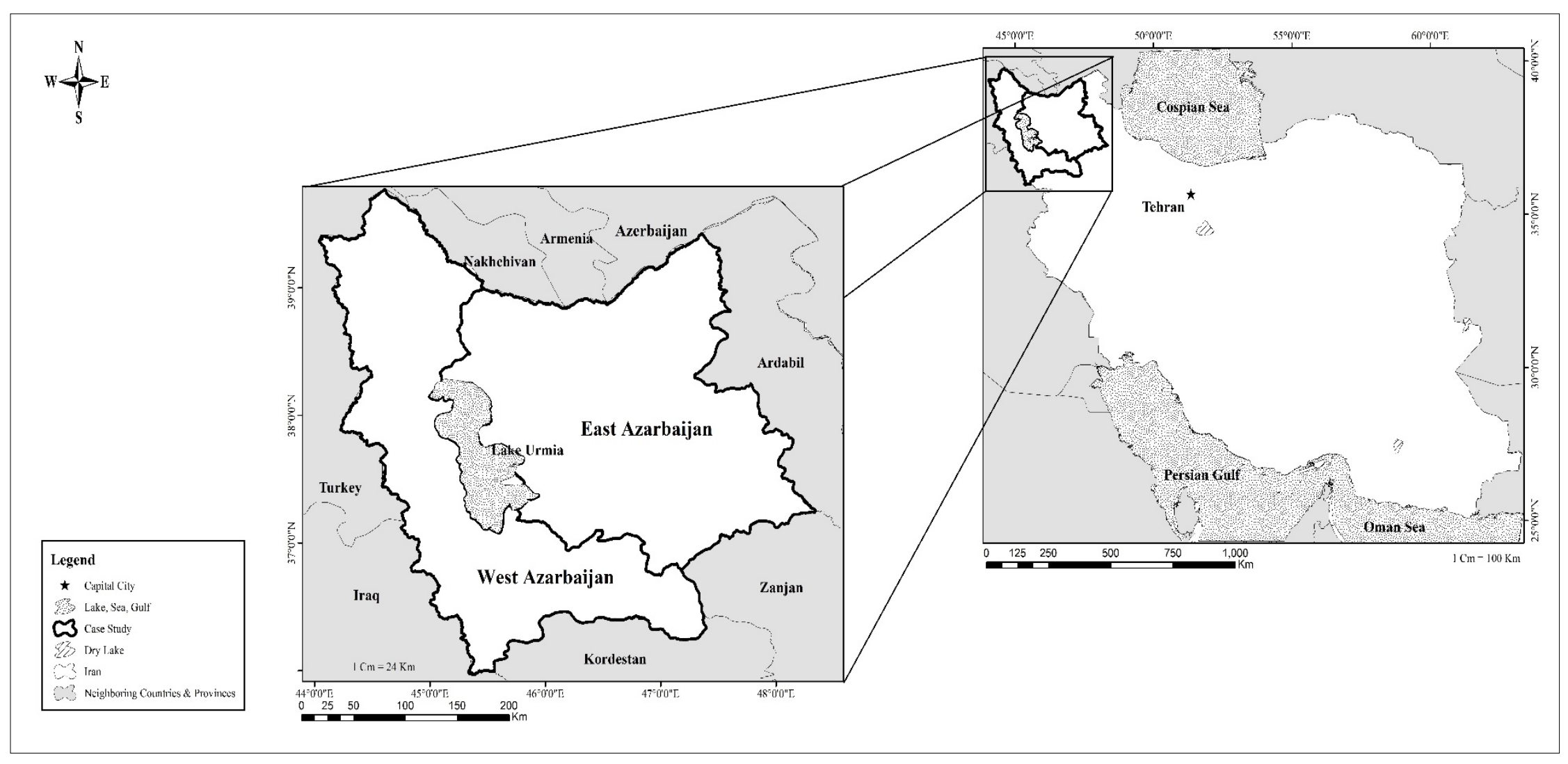

Figure 3: Location of the Studied-Area 


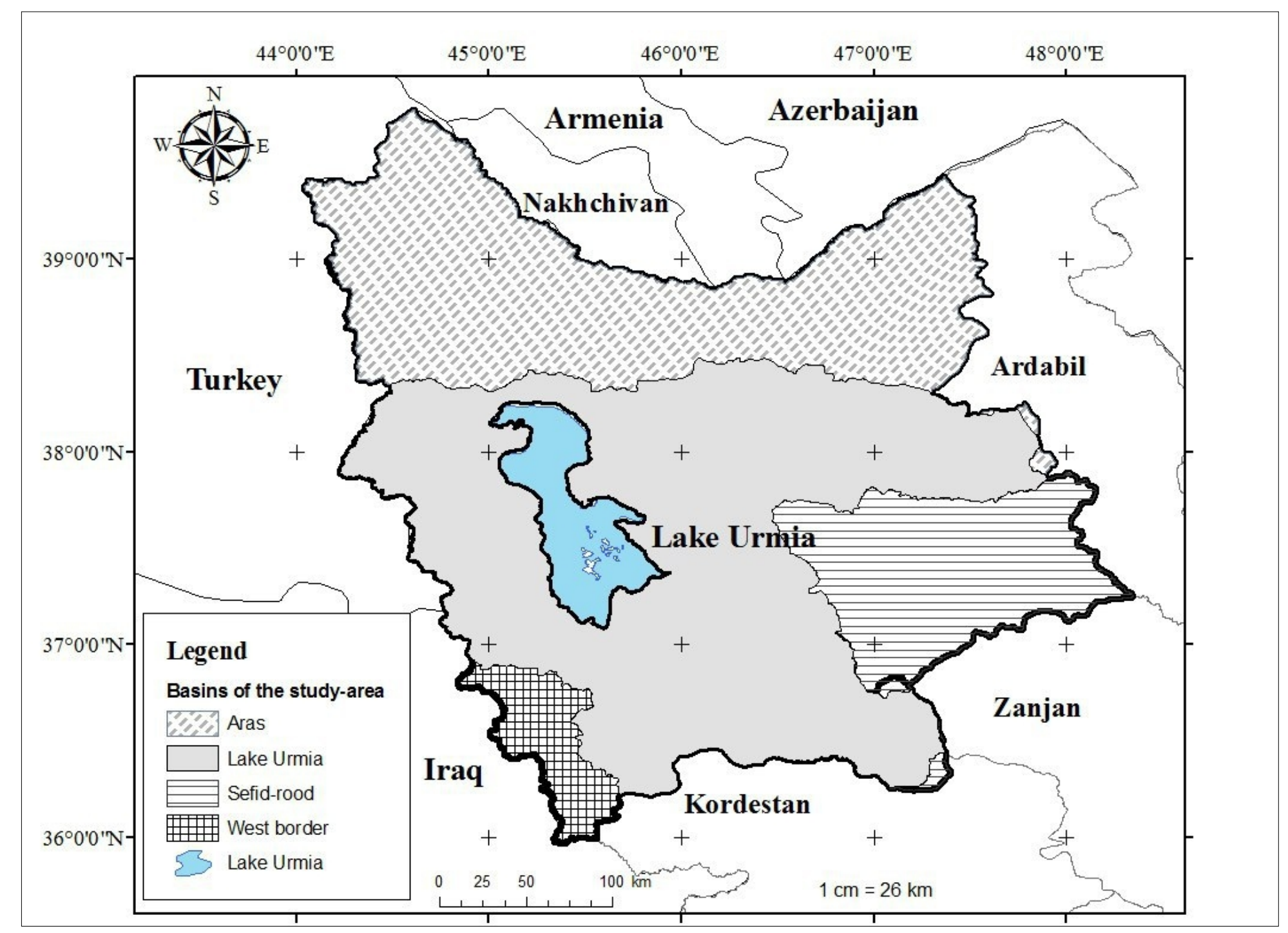

Figure 4: Location of all basins in the Case Study 


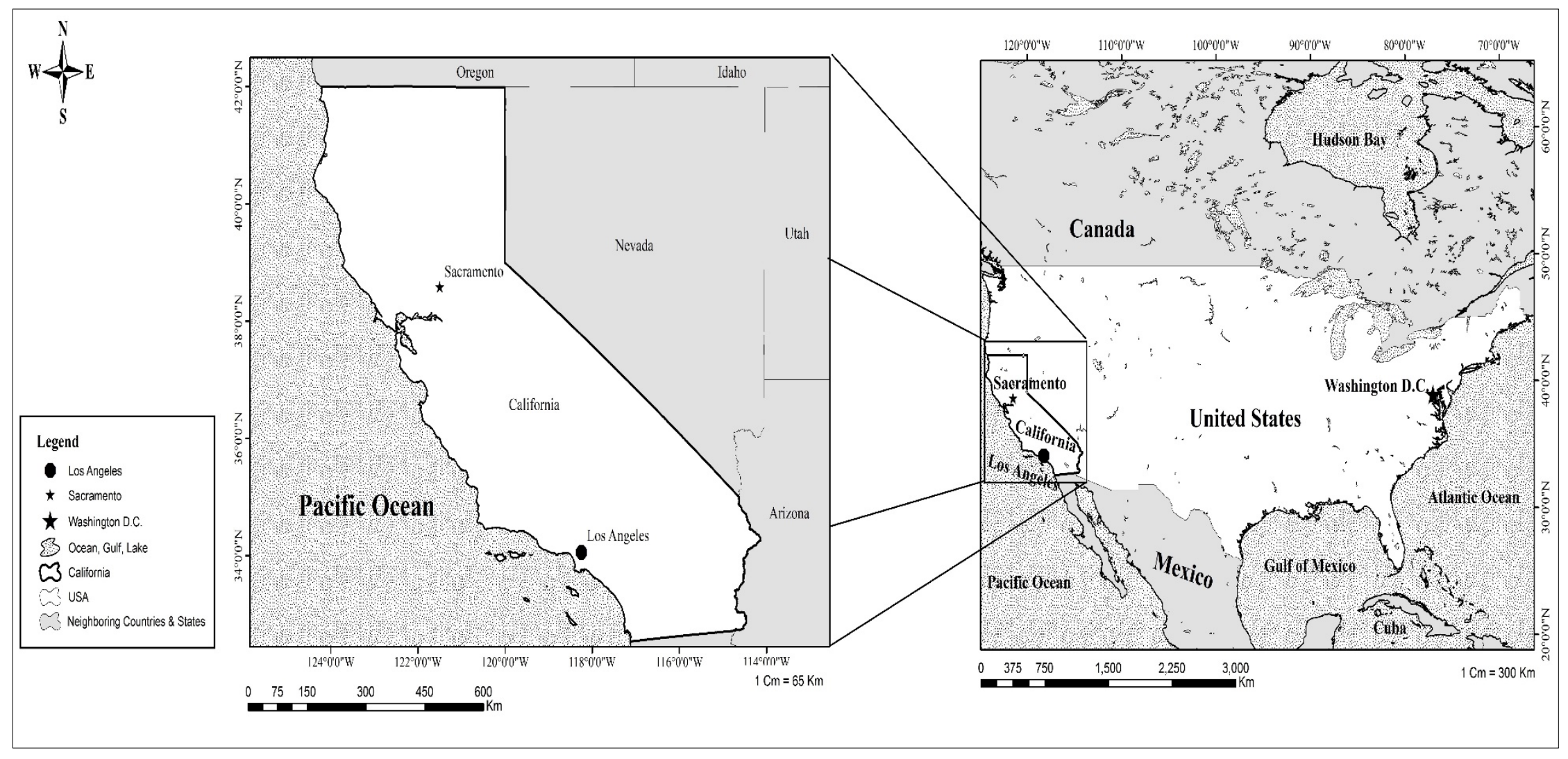

Figure 5: Location of comparing region (the state of California) 
Table 1. Cost components of charges in irrigation water sector of selected countries (Toan 2016)

\begin{tabular}{|c|c|c|c|c|c|}
\hline Countries & Pricing Agency & Subsidies $^{\text {a }}$ & Countries & Pricing Agency & Subsidies \\
\hline United States & State agencies & $\begin{array}{l}\text { All of resource costs } \\
\text { and Env. costs }\end{array}$ & Chile & Public agencies & $\begin{array}{l}\text { Part of capital costs } \\
\text { and all of Env. costs }\end{array}$ \\
\hline Croatia & Government agencies & $\begin{array}{l}\text { Part of O\&M and all } \\
\text { capital costs }\end{array}$ & Egypt & No charges & $\begin{array}{c}\text { Subsidies all to } \\
\text { farmers }\end{array}$ \\
\hline Greece & Government agencies & Part of capital costs & South Africa & Government agencies & $\begin{array}{l}\text { Part of capital costs } \\
\text { and all of resource } \\
\text { costs and Env. costs }\end{array}$ \\
\hline Portugal & Public agencies & $\begin{array}{c}\text { Small part of O\&M } \\
\text { and most of capital } \\
\text { costs }^{c}\end{array}$ & India & State agencies & $\begin{array}{c}\text { Part of O\&M costs, } \\
\text { all of other costs }\end{array}$ \\
\hline Spain & $\begin{array}{c}\text { Basin authority and Irrigation } \\
\text { districts }\end{array}$ & $\begin{array}{l}\text { Part of capital costs, } \\
\text { all of Resource costs } \\
\text { and Env. Costs }\end{array}$ & Kingdom of Jordan & Government agencies & $\begin{array}{l}\text { Part of O\&M costs, } \\
\text { all of other costs }\end{array}$ \\
\hline UK & Regions & None & Pakistan & $\begin{array}{c}\text { Provincial } \\
\text { government }\end{array}$ & $\begin{array}{c}\text { Part of O\&M costs, } \\
\text { all of other costs }\end{array}$ \\
\hline Italy & Public agencies & Part of capital costs & Turkey & $\begin{array}{l}\text { Water users' } \\
\text { organizations }\end{array}$ & $\begin{array}{c}\text { Most of capital costs } \\
\text { all of resource costs } \\
\text { and Env. costs }\end{array}$ \\
\hline Australia & Rural water businesses & $\begin{array}{l}\text { Part of capital costs } \\
\text { and all of Env. costs }\end{array}$ & Iran & $\begin{array}{c}\text { Government } \\
\text { agencies/ Provincial } \\
\text { water authorities }\end{array}$ & $\begin{array}{c}\text { Part of O\&M costs, } \\
\text { most of Capital } \\
\text { costs }^{\mathrm{d}} \text {, all of resource } \\
\text { costs and Env. costs }\end{array}$ \\
\hline New Zealand & Irrigation Companies & $\begin{array}{l}\text { All of resource costs } \\
\text { and Env. costs }\end{array}$ & China & Government agencies & $\begin{array}{l}\text { Part of O\&M costs, } \\
\text { all of other costs }\end{array}$ \\
\hline Japan & Land improvement districts & $\begin{array}{c}\text { Part of capital costs, } \\
\text { all of resource costs } \\
\text { and Env. costs }\end{array}$ & Thailand & Government agencies & $\begin{array}{l}\text { Subsidies all to } \\
\text { farmers }\end{array}$ \\
\hline South Korea & Exempt from Charges & $\begin{array}{l}\text { Subsidies all to } \\
\text { farmers }\end{array}$ & Vietnam & Government agencies & $\begin{array}{l}\text { Most part of O\&M } \\
\text { costs and all of other } \\
\text { costs }\end{array}$ \\
\hline
\end{tabular}


- ${ }^{\text {a }}$ Subsidies include O\&M costs, capital costs, resource costs and environmental costs.

- $\quad \mathrm{b}$ The state of Georgia refuses to charge farmers for irrigation water, albeit issuing permits that legalizes irrigation by farmers.

- ${ }^{\mathrm{c}}$ Considering irrigation schemes designed by a private ownership, farmers would have to pay full supply cost of water services (this type of ownership occupies nearly 75 percent $\%$ of irrigation schemes).

- The components of costs shown in the above table are as below:

- O\&M costs: operation and maintenance costs.

- Capital costs: replacement cost, interest costs, and major repair costs.

- Resource costs: opportunity costs of alternative water uses.

- Environmental costs: environmental damages due to abstraction, storage, impoundment, discharge, etc.

- Meaning and magnitude of signs: All: all element cost is subsidized (nearly $100 \%$ ); Most: a major part of the element cost is subsidized (more than $80 \%$ ); Part: a significant proportion of the cost is subsidized (between $20 \%$ and $80 \%$ ); Small part: a small proportion of the cost is subsidized (less than $20 \%$ ).

- d The information related to circumstances of irrigation water in Iran has been reported from Tahamipour et al. 2014; 16; Iran Investment and Business Guide (IIBG) 2016; and U1 Hassan et al. 2007. 
Table 2: Areas of all drainage basins' in the studied-area

\begin{tabular}{ccccc}
\hline Aras & Urmia lake & Sefid rood & West border & Total \\
\hline $25698 \mathrm{Km}^{2}$ & $41817 \mathrm{Km}^{2}$ & $11732 \mathrm{Km}^{2}$ & $3303 \mathrm{Km}^{2}$ & $82550 \mathrm{Km}^{2}$ \\
\hline
\end{tabular}

157

158

159

160 Table 3: Areas of planting crops and the crop yield of selected crops in W.AZ and E.AZ provinces and the state of 161 California

\begin{tabular}{ccccc}
\hline & \multicolumn{4}{c}{ Regions } \\
\cline { 2 - 5 } Types of Crops & E.AZ and W.AZ provinces & \multicolumn{2}{c}{ the state of California } \\
\cline { 2 - 5 } & Tons $/$ Hectare & Hectare & Tons / Hectare & Hectare \\
\hline Wheat & 2.82 & 165948.4 & 5.88 & 137264.6 \\
Barley & 2.99 & 42263.1 & 3.27 & 10119.1 \\
Sugar beets & 58.86 & 31363.6 & 120.40 & 10117.15 \\
Corn & 46.14 & 9393.4 & 50.16 & 147128 \\
Alfalfa hay & 7.93 & 155759.7 & 21.98 & 248605.9 \\
Onion & 44.66 & 6159.6 & 47.67 & 9307.778 \\
Tomato & 40.28 & 12654.6 & 136.19 & 114642.3 \\
Potato & 31.97 & 12900.4 & 47.04 & 12423.86 \\
Watermelon & 32.81 & 2646.2 & 95.34 & 5058.575 \\
\hline
\end{tabular}

162 (*Source: Based on Statistical Yearbook of West and East Azarbaijan (2015) and UC-Davis (2015) for the state of 163 California) 
171

172 Table 4: Estimated price of one cubic meter water used in producing selected agricultural crops in E.AZ and W.AZ

173 provinces (IRR).

\begin{tabular}{cccccc}
\hline \multirow{2}{*}{ Types of Crops } & $C_{w i(H)}{ }^{*}$ & $X_{i(H)}{ }^{*}$ & $C_{w i(k g)}$ & $Q_{w i}$ & $P_{w i}$ \\
\cline { 2 - 6 } & & & & & \\
\hline Wheat & 3053512 & 2821 & 1082 & 2.65 & 408 \\
Barley & 2153532 & 2981 & 722 & 6.91 & 105 \\
Sugar beets & 8623914 & 51584 & 167 & 0.34 & 498 \\
Potato & 1192161 & 29957 & 40 & 0.51 & 79 \\
Onion & 6707698 & 41749 & 161 & 0.31 & 516 \\
Tomato & 9300126 & 40703 & 228 & 0.42 & 548 \\
Watermelon & 10321168 & 33103 & 312 & 0.49 & 638 \\
Alfalfa hay & 4611926 & 7883 & 585 & 0.65 & 902 \\
Corn & 9026111 & 45679 & 198 & 0.24 & 814
\end{tabular}

175

176

177

178

179

180

181

182 
187 Table 5: Comparing the price of one cubic meter water used in producing selected agricultural crops in W.AZ and E.AZ provinces to that in the state of California by converting IRR to USD

\begin{tabular}{ccccc}
\hline Types of Crops & $\left(\mathrm{P}_{\text {wi(IRR })}\right)_{\text {WEAZP }}$ & $\left(\dot{P}_{\text {wi(USD) }}\right)_{\text {WEAZP }}$ & $\left(\mathrm{P}_{\text {wi(USD) }}\right)_{\text {CA }} *$ & $\propto_{i}$ \\
\hline Wheat & 408 & 0.016 & 0.07 & 0.22 \\
Barley & 105 & 0.004 & 0.07 & 0.06 \\
Sugar beets & 498 & 0.019 & 0.10 & 0.19 \\
Potato & 79 & 0.003 & 0.21 & 0.01 \\
Onion & 516 & 0.020 & 0.12 & 0.17 \\
Tomato & 548 & 0.021 & 0.17 & 0.12 \\
Watermelon & 638 & 0.025 & 0.15 & 0.17 \\
Alfalfa hay & 902 & 0.035 & 0.11 & 0.33 \\
Corn & 814 & 0.031 & 0.07 & 0.43 \\
\hline \multicolumn{2}{c}{ (*Source: the state of California Data has been obtained from UC-Davis (2015) database) }
\end{tabular}


204 Table 6: Estimation of the price of one cubic meter water used for producing selected crops using Purchasing Power Parity (PPP) based on USD (\$)

\begin{tabular}{cccc}
\hline Types of Crops & $\left({ }^{\prime}{ }_{\text {wi (USD })}\right)_{\text {WEAZP }}$ & $\left(\mathrm{P}_{\text {wi (USD })}\right)_{\mathrm{CA}} *$ & $\dot{\alpha}_{\boldsymbol{i}}$ \\
\hline Wheat & 0.06 & 0.07 & 0.78 \\
Barley & 0.01 & 0.07 & 0.20 \\
Sugar beets & 0.07 & 0.10 & 0.68 \\
Potato & 0.01 & 0.21 & 0.05 \\
Onion & 0.07 & 0.12 & 0.60 \\
Tomato & 0.07 & 0.17 & 0.43 \\
Watermelon & 0.09 & 0.15 & 0.59 \\
Alfalfa hay & 0.12 & 0.11 & $\mathbf{1 . 1 6}$ \\
Corn & 0.11 & 0.07 & $\mathbf{1 . 5 1}$
\end{tabular}


Table 7: Supportive policies for agriculture sector as the main demander of water in some countries (Allen 2016)

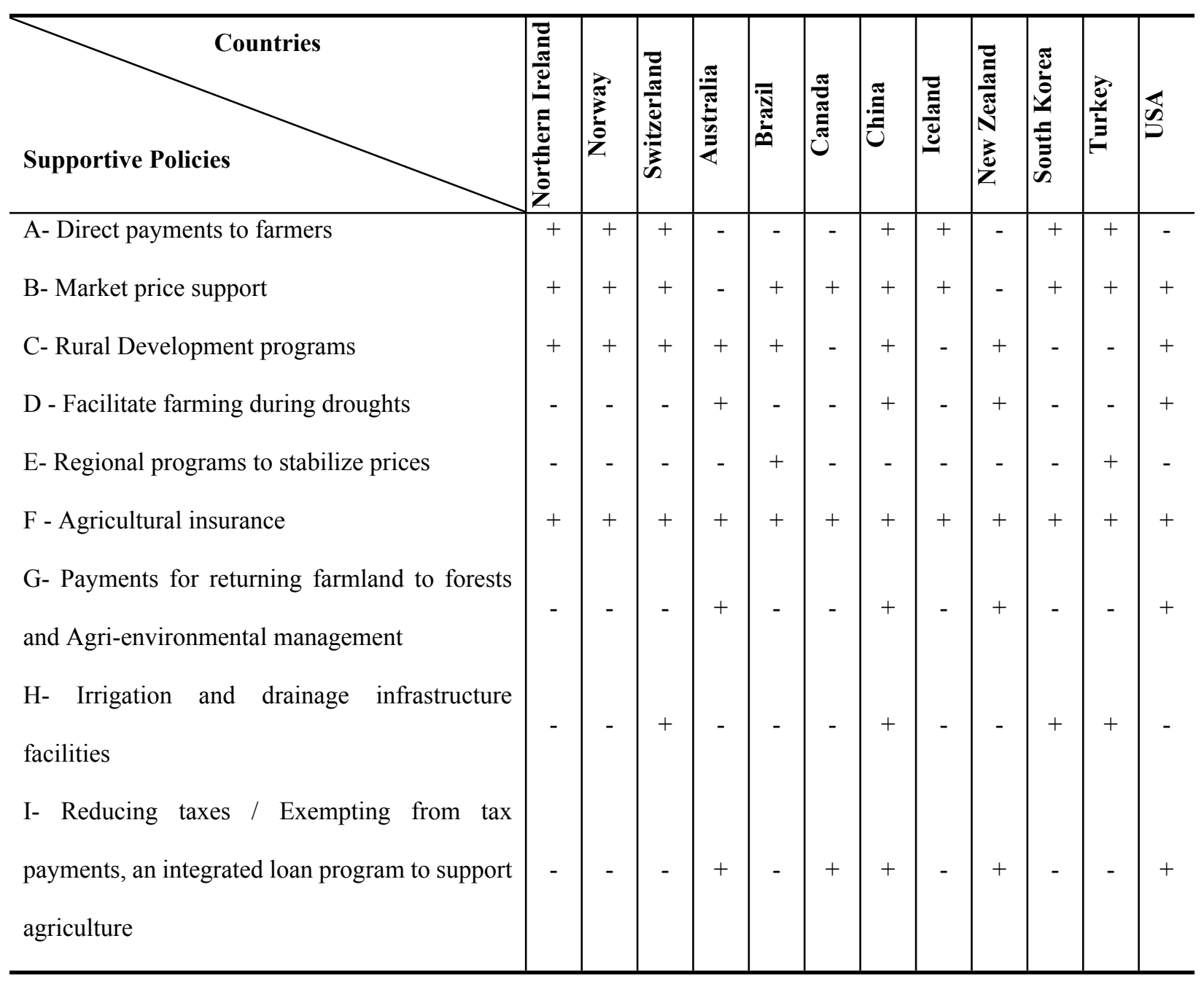

